Gorbenko O. ${ }^{1}$, Williams M. ${ }^{2}$

\title{
Looking for optimal standards, criteria and KPIs of patient centricity across the biopharma industry: an overview of existing frameworks and conceptual models (Part 1 )
}

\author{
${ }^{1}$ ViiV Healthcare, United Kingdom \\ ${ }^{2}$ Executive Insight, Switzerland
}

algostand@gmail.com,m.williams@executiveinsight.ch

\author{
Горбенко О., Вільямс М. \\ У пошуку оптимальних стандартів, критеріїв \\ та ключових індикаторів виконання завдань \\ 3 паціснт-оріснтованості у сфері біофармацевтичної \\ індустрії: огляд рамкових платформ \\ та концептуальних моделей (частина 1) \\ ViiV Healthcare, Executive Insight
}

Горбенко А., Вильямс М.

В поиске оптимальных стандартов, критериев и ключевых индикаторов выполнения заданий по пациент-ориентированности в сфере биофармацевтической индустрии: обзор существующих рамочных платформ и концептуальных моделей (часть 1) ViiV Healthcare, Executive Insight

\section{Introduction}

For a long period of time, the biopharmaceutical industry has struggled with establishing the right business model and focus on the right customers. While productfocused business models have delivered incredible innovation, they have traditionally been misaligned with the people living with medical conditions, hence failing to meet their areas of unmet need and deliver true value to them. Alongside a product-focused model, a strong priority has been on collaboration with healthcare providers (HCPs), considering them as key biopharma customers, instead of working with patients, the real end-users, who live their medical conditions day-in and day out. This has led to severe reputational, financial, legal, strategic and other consequences, which significantly affected the business of many companies [18;29]. Although, there have been the above-mentioned circumstances which could prompt to revise such strategies and re-prioritise their targets, in many cases it has not yet been done and many companies are still on the path to patient centricity, in which a key challenge is to establish new ways of working, key performance indicators and operational models [60].

Patient centricity is not an innovative paradigm for the industry: almost seventy years ago George W. Merck clearly articulated the mind-set changing vision "We try never to forget that medicine is for the people. It is not for the profits. The profits follow, and if we have remembered that, they have never failed to appear. The better we have remembered it, the larger they have been." [3]. Over the following decades, large pharmaceutical companies have highlighted their patientcentric mission and vision expressing some intentions to address patient's interests as much as possible, however, neither consolidated strategies, nor tangible operational models have been deployed as a follow-up.
The cost and time to develop new drugs has increased over the last 40 years; the cost per FDA approved drug in the 1970 's was approximately $\$ 179$ million and took 11 years to develop, however now the cost of a new FDA approved drug has been estimated at approximately $\$ 2.4$ billion and takes 15 years [11]. The cost in bringing potential new medicines through discovery, pre-clinical, clinical and regulatory approval is now far greater than before, while further challenges exist in the form of HTA/value assessment upon approval in many countries, growing public scrutiny and social responsibility/expectations, possible legal risks and other macro-environmental changes. Given these costs and challenges, the biopharmaceutical industry must focus on bringing products forward that meet remaining unmet needs and patient preferences not addressed by the existing standard of care of medical conditions. The industry can ill afford to advance potential new medicines if they do not demonstrate real value to patients, given the potentially high cost of development, as they will be unlikely to satisfy patients and also to recoup the prior investment. Holistic, timely and compliant collaboration with patients, caregivers and community representatives throughout the medicine development continuum (MDC) is becoming a critical success factor for the industry, moving from a traditional focus on HCPs as interim users, to patients as end-users of medicinal products and technologies $[6 ; 13 ; 22 ; 29]$.

Reflecting on the factors mentioned above, over the last decade the business model of the biopharmaceutical industry has been switching from product-centric to patient-centric, in which unmet patient needs and expectations may be considered as the main drivers of innovation and investment in $R \& D$ $[13 ; 35 ; 39]$. This trend varies from company to company and should be considered from a whole healthcare perspective. This is because patient centricity is not a shifting paradigm for 
only the biopharmaceutical industry, but for the whole of healthcare, as there are many other influential stakeholders and objective factors within healthcare ecosystems that should directly or indirectly deliver value to patients $[10 ; 12 ; 19]$. Public-private partnerships thus offer a strong solution for both patients and the biopharmaceutical industry to ensure that new medicines meet the remaining unmet needs and preferences of patients, whilst defining the value of new medicines early on through discussion with patients (as the product end user) and also other stakeholders (e.g. payers, HCPs, academia, regulators/HTA bodies and others) [49;53;57].

More practically the establishment of a value-delivery paradigm within healthcare and in particular industry is playing an important role, meaning that medicines are assessed not solely through their product characteristics/attributes, but include the value provided to patients and other stakeholders. This has been shown by many recent examples and trends: transformation of value-based pricing (VBP) to value-based assessment (VBA) concept across regulatory and HTA systems; substantiation of Target Value Profiles (TVP) replacing Target Product Profiles (TPP) within corporate strategic and operational systems; development of valuedriven frameworks and conceptual models on patient centricity; exploration of the implementation science methodology and innovation diffusion/healthcare utilization frameworks $[1 ; 2 ; 16 ; 23 ; 36 ; 38 ; 46]$. Additional evidence of communicating the value of health technologies/standards of care directly to patients comes from the newly established practice that many international clinical guidelines include educational tools and recommendations specially developed for patients, their relatives and caregivers [4;26;61]; initiatives to publish lay language summaries (LLSs) on the public domain and disseminate them among study participants as well as the inclusion of plain language summaries (PLSs) to scientific publications of study results [28;58].

Although the value-delivering paradigm has relatively strong theoretical pillars and supportive practical cases, in fact it has been explored disproportionately and inconsistently throughout the MDC and existing care continuums, where many involvement/engagement gaps can still be identified. A well-established approach explores the opportunities and analyses the different types of collaborations with patients throughout three principal stages of the MDC: discovery and pre-clinical; clinical development; authorisation and maturity. While the clinical development, authorisation and maturity stages have been well explored, the discovery and pre-clinical stage remains an almost unexplored area of collaboration between patients and the industry with a strong potential to bring value for both stakeholders. Such partnerships allow companies and patients to share their expertise together to help prioritise drug discovery projects of greatest interest and benefit in meeting unmet patient needs, jointly substantiate a TVP, suggest the most relevant patient-centred outcomes (PCOs) and "translate" the symptoms and other manifestations patients suffered most into real targets and pathways [22;45]. "As earlier as possible" would appear to be a basic engagement rule to avoid systematic errors, reputational losses and further disinvestments $[14 ; 19 ; 27]$. The most well explored area is clinical development in which the input from patients can be invaluable to improve study design, protocols and informed consent forms, PCO questionnaires to make them practical and understandable to patients and to increase participant recruitment and retention in clinical trials [26]. Collaboration with patients in clinical development provides mutual benefit to both stakeholders, as patient-focussed trials are better suited to patients and their needs and determine the value of a new medicine from their perspective, while for industry reducing costly and time-consuming protocol amendments given that clinical trial costs have increased significantly in recent years [17;27]. Within the late development and authorisation/HTA phase, patient engagement allows companies to best define the value messages that should be used with payers, to underline the key areas where a new drug can make a difference to patients by improving their health-related quality of life and treatment experience $[11 ; 47]$. From the other side, patient engagement can also forms a part of some HTA agencies processes to provide patients with the opportunity to share their perspectives on new technologies and to include their patient perspective in the assessment, examples of such agencies with patient engagement initiatives are: the Federal Joint Committee (G-BA), the National Institute for Health and Care Excellence (NICE), the French National Authority for Health (HAS), the National Institute for Health Research, Health Information and Quality Authority (HIQA), the Scottish Medicines Consortium (SMC), the Spanish Network of HTA Agencies, the Canadian Agency for Drugs and Technologies in Health (CADTH) and The European Network for Health Technology Assessment (EUnetHTA) [21;33;38;48;51;52;54].

A small study was recently carried out aiming to understand the perceived value of patient engagement across the MDC based on the distribution of time spent in patient engagement across each phase at 2017 and a prediction for 2022. The phases of the MDC phases were defined as: 'Discovery \& Research', 'Clinical development', 'Approval \& HTA' and 'Commercialisation'. The study was conducted with both biopharmaceutical industry and patient association stakeholders to understand both perspectives. The results highlighted that although still not sufficient, the current distribution of patient engagement amongst both stakeholders is highest in the 'Clinical development' and 'Commercialisation' phases, where patient engagement can be seen as currently best integrated and where the value is most tangible. Both stakeholders predicted that in 2022 the distribution of patient engagement would increase in 'Clinical development', providing a strong indication of further value from engagements in this stage. The current distribution of patient engagement was currently lowest in the 'Discovery \& Research' phase, although this was predicted to strongly increase in the future according to both stakeholder groups, highlighting the potential value of patient engagement in this unexplored phase, such as identifying patient unmet needs and prioritising relevant research investments with patients. The distribution of patient engagement in the 'Commercialisation' phase was highest according to both stakeholders in 2017, although both predicted that this would fall in 2022. This decrease in the time spent in patient engagement in the 'Commercialisation' phase might represent a deprioritisation, compared to the other phases, due to the emergence of 
potentially greater value from patient engagement in the other phases. The current and predicted future distribution of patient engagements in the 'Approval \& HTA' phase showed little change from the patient perspective and only a slight increase in 2022 from industry [56;57].

In 2018 PFMD (Patient Focused Medicine Development) conducted a multi-stakeholder survey to identify/define priority patient engagement activities within each stage of the MDC: 94 unique activities were identified; the working group follow-up consultations are continuing (2019-2020) to support them by real case studies and develop respective recommendations [49].

Another recent approach explores delivering value to patients throughout the disease care continuum/individual experience living with a medical condition, which goes far beyond the medicine lifecycle and includes supportive services, materials, tools/resources, communication streams, public health and environmental/societal settings [24;25;31]. This has disproportionally been addressed by some types of patient support programmes (PSPs) or services (PSSs) at the post-authorisation stage, whilst such activities have not been classified and analysed in terms of functional accountability/ responsibility, governance, compliance, format and other parameters.

Due to its operational specifics and well-established asset/product-oriented strategies, biopharmaceutical business has broadly been adopting the traditional approach, whilst there have been successfully implemented initiatives to address unmet patient needs throughout the care continuums [6;53]. It becomes obvious, that matrix-like combination of the two above mentioned approaches are considered as optimal by many biopharmaceutical companies and other healthcare stakeholders [18]. However, the published information regarding the patient-centric models/strategies that companies deploy is limited and mostly presented by separate case studies and real-life examples [35;53].

Although many conceptual frameworks and other guiding materials on patient centricity and engagement have been developed over the last decade, the main challenge remains that a solid/robust regulatory/legal framework to comprehensively model the collaboration between the industry and patients still does not exist. Nothing has been consolidated, agreed, validated, approved and therefore accepted as a healthcare-wide standard yet. National and above-national industry associations (ABPI, EFPIA, IFPMA) support industry efforts to work better with patients, community-based organisations and patient advocacy groups, but they do not provide clear engagement instructions, tangible criteria of success and KPIs [7;20;59]. Some important initiatives are underway now with the aim to provide more detailed recommendations for the industry; the $\mathrm{NHC}$ in close collaboration with the US FDA is developing the guidelines set on patient-focused drug development (PFDD) under the PDUVA VI Initiative [14;16;44], and the ongoing PFMD project has been mentioned above [49].

Taking the above presented factors, there is a need to review the existing patient engagement frameworks and conceptual models by evaluating the proposed elements (part 1) and their implementation potential/opportunity to be adopted by the biopharmaceutical industry (part 2) in close collaboration with patient organisations and patients.

\section{Objectives}

- To conduct a literature search and broader resource analysis to identify and select frameworks, conceptual models or any relevant initiatives across the biopharmaceutical industry and/or healthcare systems which focus on performance management and success evaluation of patient centeredness;

- To comprehensively assess the selected conceptual models and frameworks proposed throughout the period of 2010-2019 against several criteria and conduct contentanalysis of the proposed key elements: standards, attributes, criteria, KPIs and other impact indicators.

\section{Methods}

A literature search and content analysis of the existing frameworks, think-tanks and conceptual models was conducted in 2016-2018 as a part of the PFMD initiative with the focus on patient engagement, patient and community involvement in research, value and benefits for patients [9]. A broader search was conducted in several sources published or available since 2010 (PubMed, British Medical Journal, Social Media resources - LinkedIn and Facebook, corporate online resources, events and reports from the events, published materials and offline resources - research reports, white papers and public statements) to identify any frameworks or initiatives across the biopharmaceutical industry and/or healthcare systems that focus on performance management and success evaluation within patient centeredness. The keywords were patient centricity, patient centeredness, focus on the patient, measuring patient centricity, impact measurement, patientcentric approach, patient-centric indicators, patient-centric standards, patient-centric attributes and patient-centric criteria.

The selected conceptual models and frameworks were analysed against the following parameters: key characteristics, authorship (which stakeholders developed and proposed it, whether patient representatives were involved or not), targeted stakeholders, targeted medicine lifecycle stage or industry/ healthcare operations, proposed criteria, standards, KPIs or other indicators. The outputs of this content analysis were consolidated in table 2 to ensure granularity for further assessments. Additionally, across the frameworks and conceptual models, content of proposed criteria, standards, KPIs or other indicators were analysed in terms of wording simplicity, elements' similarity and/or repetitiveness.

\section{Results}

Overall 192 results were found through the literature search using PubMed and BMJ Open, of which 16 were relevant or somewhat relevant to the subject (11 through PubMed and 5 through BMJ Open). 13 relevant and somewhat relevant resources were also identified through a broader search using online search engines (3), social media (1), known websites or cross-references (4), events (1), offline materials and other available resources (4). In total, 29 search results were 
considered as a relevant or somewhat relevant to performance management and success evaluation within patient centeredness. All of them were checked with a particular focus on the available online resources using search engines and social media, and for 15 results such resources were found.

The 12 frameworks and conceptual models were selected as a result of holistic resources/results analysis. There have been a limited number of peer-reviewed publications on patient-centeredness across healthcare and the pharmaceutical industry, which could reflect the implementation of the selected frameworks and conceptual models over the last 10 years (2010-2019), therefore the alternative resources were analysed, which yielded data about 8 frameworks or conceptual models. The basic characteristics of the analysed patient centricity frameworks and conceptual models are summarised in the [Tab. 1].

Table 1. Basic characteristics of the selected frameworks and conceptual models of patient centricity

\section{Framework or conceptual model}

PatientView

(hereafter

PatientView) [5]

\section{PFMD (Patient Focused Medicine Development) meta-framework (hereafter PFMD) [9]}

\section{CTTI (Clinical} Trial

Transformation Initiative, hereafter CTTI) [8]

\section{Key characteristics}

Self-evaluation toolkit based on expectations from the industry expressed by patient organisations worldwide. The first edition of the toolkit was published in November 2017. 9 attributes contain key elements/questions to be assessed/answered. PatientView Consultancy uses the same attributes as criteria for the annual Corporate Reputation of the Pharmaceutical Industry survey

\section{Meta-framework with} unified quality criteria for evaluation of any patient engagement initiative driven by any stakeholder/stakeholders within medicine development and the value delivery continuums. 7 Quality criteria were substantiated with patient experts \&advocates and broadly presented in the PE Quality Guidance (2018), then the best practice examples were illustrated in the Book of Good PE Practice (2018) [53]

Set of recommendations to improve participation of patient organisations in the work of clinical trial sponsors (both the industry and academia),

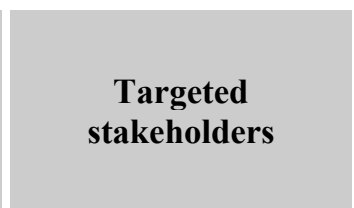

\section{Biopharma industry}

\section{Targeted medicine lifecycle stage, industry/healthcare operation, if applicable}

$\mathrm{n} / \mathrm{a}$

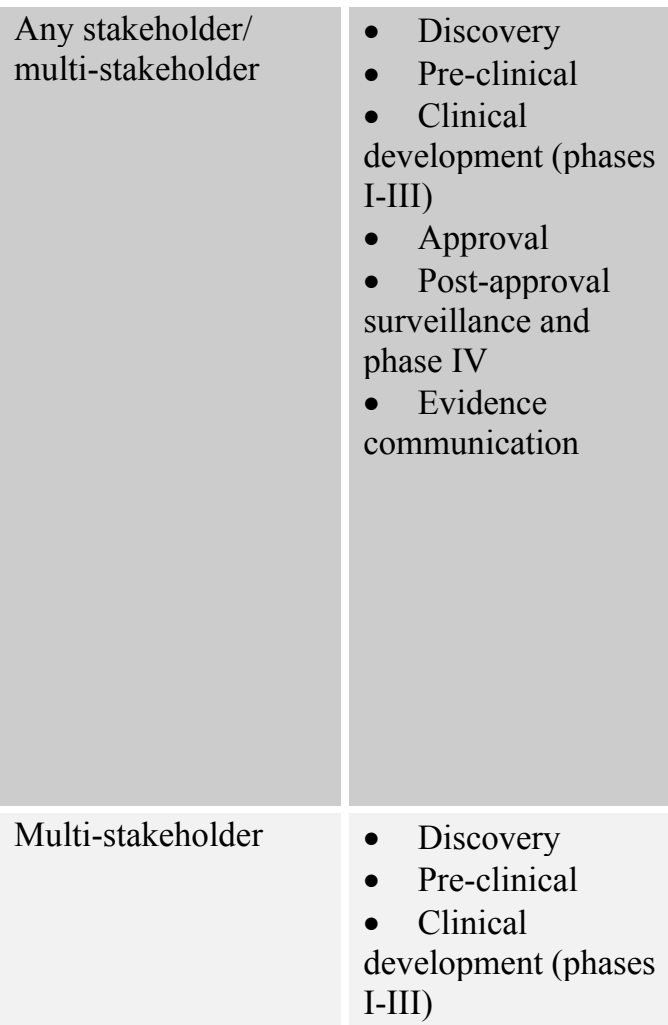

Proposed criteria, standards, KPIs or other indicators

1. Authenticity

2. Support and services

3. Transparency

4. Involvement in

R\&D

5. Quality product information

6. Patient Group relations

7. Patient safety

8. Equitable access

9. Valued products

1. Shared purpose

2. Respect and accessibility

3. Representativeness of stakeholders

4. Roles and responsibilities 5. Capacity and capabilities for engagement 6. Transparency of communication and documentation 7. Continuity and sustainability

The initiative recommends creation of a set of standard metrics to assess effectiveness of partnerships, however, 
which includes meaningful engagement of patients throughout all stages of the Medicine Development Continuum

NexGen/OxyGen (hereafter NextGen/OxyGen) patient centricity frameworks (Eyeforphrama 2017) [37]

National Health Council (NHC) Framework (hereafter NHC) [32]

PFDD Conceptual Framework or MCERSI (University of Maryland Centre of Excellence in Regulatory Science and Innovation; hereafter PFDDM-CERSI) [55]

\section{In 2017 Eyeforpharma} published the

Practitioner's Guide on patient centricity frameworks. The ways to create an efficient patient centricity framework in a biopharma company as well as essential elements of patient centricity and their measurements were discussed. NexGen and OxyGen independent assessment systems were presented [37]

Recommendations of the multi-stakeholder working group including patients to reach a consensus on what it entails to meaningfully engage patients and identify key gaps and barriers in patient engagement across drug research, development and approval

\section{The Think Tank with} participation of patient organisations, regulators (FDA), biopharmaceutical industry, payer and other stakeholders to analyse views, challenges, activities and aspirations for PFDD (Patient Focused Drug Development), as well as future direction and opportunity for collaboration. The Framework Supports FDA PFDD concept (PDUFA VI and 21st Century Cures Act)
- Approval

- Post-approval surveillance and phase IV

- Evidence communication

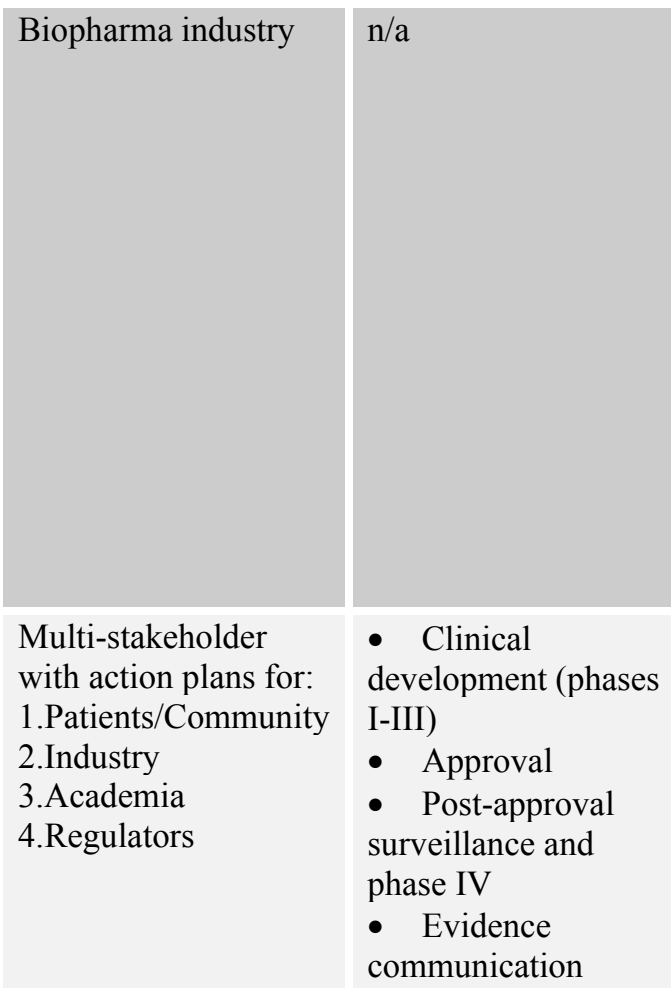

\section{Multi-stakeholder}

- Discovery

- Pre-clinical

- Clinical development (phases I-III)

- Approval

- Post-approval surveillance and phase IV

- Evidence

communication the standards themselves aren't defined. The key recommendations are:

- Early involvement

- Comprehensiveness

- Mutual transparency and confidentiality

- Diversity and representativeness

Key elements of the NexGen assessment industry-standard framework on patient centricity:

1. Innovation

2. Vision

3. Governance

4. Insights

5. Activities

6. Sharing

7. Evaluation

OxyGen is a checklist to evaluate patientcentred care by pharma.

- Focus on meaningfulness and the related criteria/questions to assess engagement (What? Who? When?

How? Expected impact? Actual Impact?)

- Criteria of best practice examples of patient engagement

Engagement level can be evaluated by the gradual criteria:

- Patient role

- Continuity

- Meaningfulness

- Representativeness

- Temporality 


\section{KINAPSE \\ conceptual model \\ for managing \\ performance in \\ patient centricity \\ by pharma \\ (hereafter \\ KINAPSE) [30]}

\section{Patient Centred}

Outcomes

Research Institute

(PCORI)

engagement rubric (hereafter PCORI)

$[40,41]$

$[40,41]$

National Institute

for Health

Research (UK

NIHR) INVOLVE

(hereafter

INVOLVE) [34]
In 2015 Kinapse (Syneos

Health now) developed

the sets of external and

internal patient value

KPIs categories for

pharma based on

fundamental

measurement approaches

used to monitor patient

benefit within healthcare, such as outcomes, patient experience, patient activation, process and volume. Kinapse highlights the key success factors to meet the requirements:

understanding and stratification of the patient population; effective prioritisation and resource allocation; robust and compliant means of engagement; transparency and tailoring unmet patient needs

\section{PCORI engagement} principles are developed to illustrate and provide guidance around how input from patients and other stakeholders can be incorporated throughout the entire research process with the particular focus on study planning, conduct and dissemination

INVOLVE - the UKbased community advisory group focused on public involvement in research. The group includes patient experts \& advocates. There is the set of recommendations agreed by independent experts bringing together expertise, insights and experience to advance public involvement as an essential part of the process by which research is identified, prioritised, designed, conducted and disseminated. The six national standards for
Biopharma industry $\quad \mathrm{n} / \mathrm{a}$

External KPI categories include:

- Patient outcomes (including patient activation)

- Patient experience

- Access and adherence (external process) Internal KPI categories include:

- Strategy

- Capability

- Process (internal)

\begin{tabular}{|c|c|c|}
\hline Multi-stakeholder & $\begin{array}{l}\text { - Pre-clinical } \\
\text { - Clinical } \\
\text { development (phases } \\
\text { I-III) } \\
\text { - Evidence } \\
\text { communication }\end{array}$ & $\begin{array}{l}\text { - Reciprocal } \\
\text { relationships } \\
\text { - Co-learning } \\
\text { - Transparency, } \\
\text { honesty and trust } \\
\text { - Partnerships } \\
\text { throughout study } \\
\text { planning, conduct and } \\
\text { dissemination } \\
\text { - Supported by real- } \\
\text { world examples }\end{array}$ \\
\hline $\begin{array}{l}\text { Multi-stakeholder } \\
\text { with the focus on the } \\
\text { joint working } \\
\text { between researches } \\
\text { (vary), HCPs and } \\
\text { public sector }\end{array}$ & $\begin{array}{l}\text { - Pre-clinical } \\
\text { - Clinical } \\
\text { development (phases } \\
\text { I-III) } \\
\text { - Approval } \\
\text { - Post-approval } \\
\text { surveillance and } \\
\text { phase IV } \\
\text { - Evidence } \\
\text { communication }\end{array}$ & $\begin{array}{l}\text { Key elements of co- } \\
\text { producing a research } \\
\text { project: } \\
\text { - Sharing of power } \\
\text { - Reciprocity } \\
\text { - Respecting and } \\
\text { valuing the knowledge } \\
\text { of all those working } \\
\text { together on the research } \\
\text { - Including all } \\
\text { perspectives and skills } \\
\text { - Building and } \\
\text { maintaining } \\
\text { relationships } \\
\text { Respectively, the } \\
\text { standards are: } \\
\text { 1. Inclusive } \\
\text { opportunities } \\
\text { 2. Working together }\end{array}$ \\
\hline
\end{tabular}


public involvement in research (2017) [ref

standards] and the guidance on co-producing research project (2018) [ref guidance] were developed and based on the INVOLVE principles

Perfetto et al,
Framework
(hereafter Perfetto)
[43]

FastCures Value Framework (hereafter FastCures) [15]

This value-based

framework was developed by the thinktank to determine gaps in

The value-driven
framework examines the
factors that may affect the
pace of evidence
adoption and application
into routine clinical
practice. Aday\&
Andersen and Rogers'
framework/model of
innovation diffusion and
healthcare utilization
were used as baselines
[2;46]
assessing value of treatment options and based on the 4 earlier established frameworks/ approaches within oncology (ASCO, ICER, MSK Drug Abacus and $\mathrm{NCCN}$ )

National Voices,
UK (hereafter
National Voices)
$[42 ; 50]$
This conceptual model has been adapted by the patient advocates from the Reputation Institute's Global Pharma RepTrak Domains summarising the key attributes of corporate reputation within the industry

\begin{tabular}{|c|c|}
\hline $\begin{array}{l}\text { Multi-stakeholder, } \\
\text { segmented by sectors: } \\
\text { •Public } \\
\text { •Private } \\
\text {-Academic }\end{array}$ & $\begin{array}{l}\text { - Post-approval } \\
\text { surveillance and } \\
\text { phase IV } \\
\text { - Evidence } \\
\text { communication }\end{array}$ \\
\hline Multi-stakeholder & $\begin{array}{l}\text { - Clinical } \\
\text { development (phases } \\
\text { I-III) } \\
\text { - Post-approval } \\
\text { surveillance and } \\
\text { phase IV } \\
\text { - Evidence } \\
\text { communication }\end{array}$ \\
\hline
\end{tabular}

3. Support and learning

4. Communications

5. Impact

6. Governance and maturity of the science the science

- Applicability

- Integration into guidelines

5 domains of patient value and technical criteria:

- Patient-centred outcomes costs
- Validity, reliability

- Communication of

- Economic drivers

- Patient preferences

- Patient and Family

- Quality and applicability of evidence

- Usability and transparency

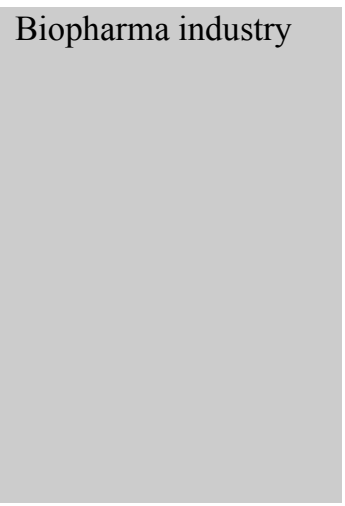

- Products/services

- Innovation (in partnership with patients)

- Workplace

- Citizenship (responsibility, ethics, transparency)

- Leadership

- Performance

(perform well for all stakeholders)
The initial analysis of the selected frameworks and conceptual models demonstrated their significant diversity, heterogeneity and inconsistency in terms of the presented format, key characteristics, targeted stakeholders, targeted medicine lifecycle stage or industry/healthcare operations, proposed criteria, standards, KPIs or other key elements. Although, some frameworks or conceptual models have prototypes and development history based on key elements of other frameworks/models (PFMD and INVOLVE; FastCures and its predecessors: ASCO, ICER, MSK Drug Abacus and NCCN; Perfetto framework and Aday\&Andersen and Rogers' framework/model of innovation diffusion and healthcare utilization), they are not aligned and agreed between each other. This makes the task of consolidation, harmonisation and unification even more complex. On the other hand, further content-analysis of the proposed criteria, standards, KPIs or other indicators showed a certain similarity and repetitiveness of some elements in several frameworks and conceptual models, highlighting their comparable subject focuses and priorities [Tab. 2].

The biopharmaceutical industry has not solely developed any of the selected frameworks or conceptual 
models, whilst industry representatives took part in the crosssector think tanks and working groups under the multistakeholder, pre-competitive taskforces driven by external consultancies or independent consultants. Such input does not reflect the strategic and operational specifics of the industry with some exceptions for the R\&D-focused frameworks (PFMD, PFDD-M-CERSI, CTTI and INVOLVE), where the industry is traditionally considered as a main sponsor alongside academic research institutions. 4 of the selected frameworks or conceptual models are targeted entirely to the biopharmaceutical industry (PatientView, NextGen/OxyGen, KINAPSE and National Voices), the other 8 are multi-stakeholder and open for collaboration with patients, patient organisations, HCPs, biopharmaceutical industry, academic research institutions, regulators, HTA agencies and other stakeholders. There is quite common segmentation by government, non-government (public) and private sectors within the selected frameworks and models. One value-based framework (Perfetto) includes the academic sector alongside public and private sectors.

The 8 of 12 analysed frameworks and conceptual models tend to consider specific phases of the medicine development continuum (MDC) or R\&D operations with more or less detailed segmentation: discovery, pre-clinical development, clinical development (phases I-III), approval/ authorisation, post-approval/surveillance and phase IV, evidence communication. There is a common R\&D-driven approach to define types and format of patient engagement activities, which has been enhanced by PFMD (Global) and PFDD (US) initiatives over the last years. Nevertheless, the 2 value-driven frameworks from this group (Perfetto and FastCures) operate with stages of "innovation's diffusion and healthcare utilisation", value delivery and care continuums for certain diseases. In comparison with a more traditional R\&Ddriven approach, there are less definitive and less unified approaches, which could be more applicable for dedicated diseases or therapeutic areas. The industry-oriented frameworks or conceptual models do not specify any product lifecycle phase, commercialisation stage or functional accountability, whilst the key elements of the 3 (PatientView, KINAPSE and Next Gen/OxyGen) are reflecting traditional corporate paradigms, strategic foundations and processes, such as, capabilities development, insights, vision, governance, activities, operations etc. PatientView framework consolidates the key groups of community expectations from the industry which require broader involvement of several corporate functions to ensure patient centredness, however, the functions are not specified and therefore tasked. The National Voices conceptual model introduces the original approach of patient centricity evolution from the stage of passive involvement to the stage of co-creation/co-development.

Table 2. Key elements cross-referenced and referenced within the selected frameworks and conceptual models

\begin{tabular}{|c|c|c|c|}
\hline Key element & Variations/similar elements & $\begin{array}{l}\text { Number of } \\
\text { references }\end{array}$ & $\begin{array}{c}\text { Frameworks } \\
\text { or conceptual models }\end{array}$ \\
\hline \multicolumn{4}{|c|}{ ATTRIBUTABLE ELEMENTS } \\
\hline Transparency & $\begin{array}{l}\text { Transparency of communication and } \\
\text { documentation; Mutual transparency and } \\
\text { confidentiality; Transparency, honesty and } \\
\text { trust; citizenship (including transparency); } \\
\text { communication of the science; } \\
\text { communication; usability and transparency }\end{array}$ & 8 of 12 & $\begin{array}{l}\text { PatientView, PFMD, } \\
\text { CTTI, PCORI, National } \\
\text { Voices, Perfetto, } \\
\text { INVOLVE, FastCures }\end{array}$ \\
\hline Reciprocity & $\begin{array}{l}\text { Reciprocal relationships; shared purpose; } \\
\text { sharing; performance (perform well for all } \\
\text { stakeholders) }\end{array}$ & 5 of 12 & $\begin{array}{l}\text { INVOLVE, PCORI, } \\
\text { PFMD, NexGen/OxyGen, } \\
\text { National Voices }\end{array}$ \\
\hline $\begin{array}{l}\text { Diversity and } \\
\text { representativeness }\end{array}$ & $\begin{array}{l}\text { Representativeness of stakeholders; inclusive } \\
\text { opportunities }\end{array}$ & 4 of 12 & $\begin{array}{l}\text { PFMD, CTTI, PFDD-M- } \\
\text { CERSI, INVOLVE }\end{array}$ \\
\hline $\begin{array}{l}\text { Capacity and capabilities } \\
\text { for engagement }\end{array}$ & $\begin{array}{l}\text { Capability; including all perspectives and } \\
\text { skills; co-learning }\end{array}$ & 4 of 12 & $\begin{array}{l}\text { PFMD, KINAPSE, } \\
\text { INVOLVE, PCORI }\end{array}$ \\
\hline Meaningfulness & Impact & 3 of 12 & $\begin{array}{l}\text { PFDD-M-CERSI, NHC, } \\
\text { INVOLVE }\end{array}$ \\
\hline Roles and responsibilities & $\begin{array}{l}\text { Patient role; citizenship (including } \\
\text { responsibility) }\end{array}$ & 3 of 12 & $\begin{array}{l}\text { PFMD, PFDD-M-CERSI, } \\
\text { National Voices }\end{array}$ \\
\hline $\begin{array}{l}\text { Continuity and } \\
\text { sustainability }\end{array}$ & Continuity & 2 of 12 & PFMD, PFDD-M-CERSI \\
\hline Comprehensiveness & $\begin{array}{l}\text { Partnership throughout study planning, } \\
\text { conduct and dissemination }\end{array}$ & 2 of 12 & CTTI, PCORI \\
\hline Co-leadership & $\begin{array}{l}\text { Sharing of power; co-working, cooperation, } \\
\text { co-creation }\end{array}$ & 2 of 12 & $\begin{array}{l}\text { National Voices, } \\
\text { INVOLVE }\end{array}$ \\
\hline Authenticity & Citizenship (including ethics) & 2 of 12 & $\begin{array}{l}\text { PatientView, National } \\
\text { Voices }\end{array}$ \\
\hline
\end{tabular}




\begin{tabular}{|c|c|c|c|}
\hline Respect and accessibility & $\begin{array}{l}\text { Respecting and valuing the knowledge of all } \\
\text { those working together on the research }\end{array}$ & 2 of 12 & PFMD, INVOLVE \\
\hline \multicolumn{4}{|c|}{ INFRASTRUCTURAL AND PROCEDURAL ELEMENTS } \\
\hline $\begin{array}{l}\text { Valued products and } \\
\text { quality product } \\
\text { information }\end{array}$ & $\begin{array}{l}\text { Quality and applicability of evidence; validity, } \\
\text { reliability and maturity of the science; } \\
\text { applicability and integration into guidelines }\end{array}$ & 3 of 12 & $\begin{array}{l}\text { PatientView, FastCures, } \\
\text { Perfetto }\end{array}$ \\
\hline Governance & The same element & 2 of 12 & $\begin{array}{l}\text { INVOLVE, } \\
\text { NextGen/OxyGen }\end{array}$ \\
\hline Innovation & Innovation (in partnership with patients) & 2 of 12 & $\begin{array}{l}\text { NexGen/OxyGen, National } \\
\text { Voices }\end{array}$ \\
\hline Patient-Centred Outcomes & Patient outcomes (including patient activation) & 2 of 12 & KINAPSE, FastCures \\
\hline Equitable Access & Access and adherence (external process) & 2 of 12 & PatientView, KINAPSE \\
\hline Support and services & Support and learning & 2 of 12 & PatientView, INVOLVE \\
\hline Working together & $\begin{array}{l}\text { Patient Group Relations; Building and } \\
\text { maintaining relationships }\end{array}$ & 2 of 12 & INVOLVE, PatientView \\
\hline Involvement in R\&D & Early involvement & 2 of 12 & PatientView, CTTI \\
\hline Best practice examples & Real world examples & 2 of 12 & NHC, PCORI \\
\hline Economic drivers & Patient and family costs & 2 of 12 & Perfetto, FastCures \\
\hline Patient safety & No similar elements & 1 of 12 & PatientView \\
\hline Vision & No similar elements & 1 of 12 & NexGen/OxyGen \\
\hline Insights & No similar elements & 1 of 12 & NexGen/OxyGen \\
\hline Activities & No similar elements & 1 of 12 & NexGen/OxyGen \\
\hline Evaluation & No similar elements & 1 of 12 & NexGen/OxyGen \\
\hline Strategy & No similar elements & 1 of 12 & KINAPSE \\
\hline Patient experience & No similar elements & 1 of 12 & KINAPSE \\
\hline Process (internal) & No similar elements & 1 of 12 & KINAPSE \\
\hline Patient preferences & No similar elements & 1 of 12 & FastCures \\
\hline
\end{tabular}

The deeper content analysis of the selected frameworks and conceptual models allowed the authors to categorise the key proposed elements by two groups: the group of attributable elements, which refers to desirable/expected attributes of good patient engagement and group of infrastructural/procedural elements, which includes elements regarding "ways of working". The 30 key elements were categorised, in total: $11-$ within the group of attributable elements where the similar elements were identified from other frameworks or conceptual models, and 19 - within the group of infrastructural/procedural elements, in which 9 elements were not identified in other frameworks or conceptual models (10 elements were identified in the frameworks/conceptual models). Some elements were not categorised due to unclear meaning, absent definition or other reasons: temporality (PFDD-M-CERSI); citizenship (National Voices) - because of the proposed sub-elements of "Citizenship" are relevant to 3 other key elements; products/ services and workplace - due to unclear connotation (National Voices). The proposed categorisation by groups could be useful for further reviews, prioritisation, summarisation and substantiation of patient-centricity standards within the biopharmaceutical industry.

In the group of attributable elements, the element of transparency (with some variations and connotations) had the highest number of references in several frameworks or conceptual models. Other five elements - reciprocity, diversity and representativeness, capacity and capabilities for engagement, meaningfulness, roles and responsibilities have more than two references across the selected frameworks and conceptual models. The five attributable elements (continuity and sustainability, comprehensiveness, coleadership, authenticity, respect and accessibility) had two references, which can also demonstrate some similarity between the frameworks.

In the group of infrastructural/procedural elements, only both elements of the PatientView framework - valued products and quality product information have the highest number of references and similar connotations across several frameworks and conceptual models ( 3 references). Some similarity between the frameworks has also been demonstrated for the other 9 elements - governance, innovation, patient-centred outcomes, equitable access, support and services, working together, involvement in R\&D, best practice examples and economic drivers (at least 2 references). Whilst for other elements, such as patient safety, vision, insights, activities, evaluation, strategy, patient experience, process (internal) and patient preferences similar elements or relevant references were not identified within the selected frameworks and conceptual models. Notably, those infrastructural/procedural elements were presented by value-based (FastCures) or the industry-targeted frameworks (PatientView, KINAPSE, NextGen/OxyGen), which reflects their more specialised focus. 


\section{Discussion}

Although the conducted content analysis has demonstrated some level of similarity of all attributable and a number of the infrastructural/procedural key elements, each conceptual model/framework considers certain aspects of patient engagement across healthcare and the biopharmaceutical industry, which differs from others. There is no consistent, unified methodology to evaluate the success of patient engagement and measure patient centricity within a given organisation. The proposed key elements, such as standards, KPIs, attributes and other indicators cannot be compared to or assessed against the widely accepted standards or generic indicators, because of their absence, no benchmarking precedence or consolidation efforts in the past and high level of heterogeneity. Some frameworks and conceptual models have proposed the highest number of key elements with cross-referencing (the top- 7 with 3 or more references are: transparency, reciprocity, diversity and representativeness, capacity and capabilities for engagement, meaningfulness, roles and responsibilities, valued products and quality product information): PFMD, INVOLVE, PatientView and PFDD-M-CERSI. Other frameworks and conceptual models, predominantly industry-oriented, proposed more infrastructural/procedural elements (patient safety, vision, insights, activities, evaluation, strategy, patient experience, process, patient preferences) with lower level of cross-referencing and higher heterogeneity, but they also should be taken into consideration.

\section{Conclusions}

Although the authors understand the limitations of this research (limited data available, absence of a robust methodology to evaluate patient centricity across the industry, underrepresented patient perspective in the analysed/existing frameworks and conceptual models, absence of widely accepted prototypes to compare the proposed key elements, inconsistency and heterogeneity of the considered attributable and infrastructural/procedural key elements, which have not been validated and piloted), this is a first attempt to categorise and analyse the frameworks and conceptual models of patient centricity developed over the last decade.

Overall, the selected and analysed frameworks/ conceptual models can be considered as valuable pillars for codevelopment of industry-wide patient-centric standards and KPIs together with patient communities. The separate key elements have much higher cross-referencing within the analysed frameworks/conceptual models, such as diversity and representativeness, reciprocity, transparency, capacity and capabilities for engagement, meaningfulness, roles and responsibilities (attributable elements), valued products and quality product information (infrastructural/procedural element) they should be taken as basic standards of patient centricity for industry functions, business units and local affiliates. Other elements, even with lower cross-referencing should also be taken into consideration, especially the infrastructural/procedural elements that are more specific for the industry.

These findings and interim milestones should be the subject for further research and publications, in particular with the focus on piloting, validation and broader adoption of certain patient-centric standards, impact indicators and/or KPIs across the several organisations of biopharmaceutical industry.

\section{References}

1. Abelson J (Editorial). Patient engagement in health technology assessment: what constitutes 'meaningful' and how we might get there. Journal of Health Services Research \&Policy; 2018; 0(0) 1-3.

2. Aday LA, Andersen R. A Framework for the Study of Access to Medical Care. Health Services Research; 1974 Fall; 9(3): 208-220.

3. Address to the Medical College of Virginia, Richmond (1 Dec 1950). Quoted in James C. Colling and Jerry I. Porras, Built to Last (1994, 1997), 48.

4. AIDS info: offering information on HIV/AIDS treatment, prevention and research; Access mode: https://aidsinfo.nih.gov/understanding-hiv-aids/fact-sheets

5. Being Patient-Centric: An evidence-based self-evaluation toolkit for pharma...as recommended by patient groups. PatientView; November 2017.

6. Boutin M, Dewulf L, Hoos A, et al. Culture and process change as a priority for patient engagement in medicines development. Ther Innov Regul Sci 2017; 51:29-38.

7. Code of practice 2019. IFPMA; Access mode: https:/www.ifpma.org/wp-content/uploads/2018/09/IFPMA_Code_ of_Practice_2019.pdf.

8. CTTI Clinical Trial Transformation Initiative. CTTI recommendations: effective engagement with patient groups around clinical trials, October 2015. Access mode: https://www.ctti-clinicaltrials.org/files/pgctrecs.pdf.

9. Deane K, Delbecque L, Gorbenko O, et al. Co-creation of patient engagement quality guidance for medicines development: an international multi-stakeholder initiative. BMJ Innovation 2019; 0:1-13.

10. Dewulf L. Patient Engagement by Pharma - Why and How? A Framework for Compliant Patient Engagement. Therapeutic Innovation \& Regulatory Science.2015; 49 (1):9-16. 
11. Di Masi JA, Grabowski, Hansen RW. Innovation in the pharmaceutical industry: New estimates of R\&D costs; J Health Econ. 2016 May; 47:20-33.

12. Du Plessis D, Sake J-K, Halling K, et al. Patient Centricity and Pharmaceutical Companies: Is It Feasible? Therapeutic Innovation\& Regulatory Science, 2017:1-8.

13. Enhancing productivity in biopharmaceutical R\&D. Kinapse White Paper, 2018. Access mode: https://kinapse.com/wp-content/uploads/2018/06/Kinapse-Enhancing-productivity-in-RD.pdf?aliId=eyJpIjoiMFFETHNJcTVh WUtUb1dxMSIsInQiOiJaMlBoMW1QN0dxTFYwM0Uweng5QkJRPT0ifQ\%253D\%253D

14. FastCures, Enhancing Integration of Patient Perspective Data in the Drug Development Process, Proposal for PDUFA VI [Electronic resource]. - Access mode : http://www.nationalhealthcouncil.org/sites/default/files/FasterCuresPDUFA-Comment-Letter-FDA.pdf.

15. FasterCures Value Framework: Integrating the Patient Perspective into the Development of Value Frameworks, March 2016. Access mode: http://www.fastercures.org/reports/view/56.

16. FDA Patient-Focused Drug Development Guidance Series for Enhancing the Incorporation of the Patient's Voice in Medical Product Development and Regulatory Decision Making; Access mode: https://www.fda.gov/drugs/developmentapproval-process-drugs/fda-patient-focused-drug-development-guidance-series-enhancing-incorporation-patients-voicemedical Assessed June 2019.

17. Gemeinsamer Bundesausschuss. The patient participation and the leading organizations, 2019 (https://patientenvertretung.g-ba.de/en/).

18. Gorbenko OV. Beyond the rhetoric and traditional advocacy: Walking the patient-centric talk to deliver meaningful change. Oral presentation at the Patient Summit Europe 2018, 16 October, London; https://eyeforpharma.com/conferencematerial/patient2018.php.

19. Gorbenko OV. The role of patients and community representatives in value-based assessment of health technologies and respective decision-making processes within healthcare. Economy and legislation of health care 2(4) 2016; 10-23.

20. Health Collaboration Guide 2017. EFPIA; Access mode: https:/www.efpia.eu/media/288506/efpia-healthcollaboration-guide_2017_v13.pdf.

21. Health Information and Quality Authority. Guidelines for Stakeholder Engagement in Health Technology Assessment in Ireland, 2014 (https:/www.hiqa.ie/system/files/HTA-Guidelines-Stakeholder-Engagement.pdf).

22. Hoos A, Anderson J, Boutin M, et al. Partnering With Patients in the Development and Lifecycle of Medicines: A Call for Action. Ther Innov Regul Sci. 2015 Nov;49(6):929-939.

23. Houses of Parliament. The Parliamentary Office of Science and Technology, POST note \#487 January 2015 Value Based Assessment of Drugs [Electronic resource]. - Access mode: www.parliament.uk/post.

24. International Advisory Panel on HIV Care Continuum Optimization. IAPAC Guidelines for Optimizing the HIV Care Continuum for Adults and Adolescents. Journal of the International Association of Providers of AIDS Care 2015; 14(Supplement 1) S3-S34.

25. Lasarus JV, Safreed-Harmon K, Barton SE, et al. Beyond viral suppression of HIV - the new quality of life frontier. BMC Med. 2016 Jun 22;14(1):94.

26. Leading Strategies for Effective Patient Recruitment and Retention. Principles, Priorities, and Plans for Life Science Organisations. Kinapse White paper 2018; Access mode: https://info.kinapse.com/effective-patient-rentention.html.

27. Levitan B, Getz K, Eisenstein E, et al. Assessing the Financial Value of Patient Engagement: A Quantitative Approach from CTTI's Patient Groups and Clinical Trials Project. Ther Innov Regul Sci. 2018 Mar;52(2):220-229.

28. Lobban D, Arnstein L, Wadsworth AC, et al. Plain language summaries of publications: Addressing the HOW via a stakeholder survey and workshop. Poster presentation at the $15^{\text {th }}$ Annual Meeting of ISMPP; April 15-17, 2019; National Harbor, MD, USA.

29. Lowe MM, Blaser DA, Cone L et al. Increasing Patient Involvement in Drug Development; Value in Health, 2016, V.19; 6: 869-878.

30. Managing Performance in Patient Centricity. Making the link between value for patients and value for the pharmaceutical industry. A Kinapse white paper; 2015: https://info.kinapse.com/patient-centricity.html.

31. Marcotullio S, Osorio D, Martini M, et al. Challenges in understanding the health-related quality of life of people living with HIV: a $4^{\text {th }} 90$ measure in Italy. Journal of HIV and Ageing; 2018;V.3 (3):57-61.

32. National Health Council (NHC) Framework Dialogue / Advancing Meaningful Patient Engagement in Research, Development, and Review of Drugs, September 22, 2015. Access mode: http://www.nationalhealthcouncil.org/sites/default/ files/PatientEngagement-WhitePaper.pdf.

33. National Institute for Health and Care Excellence. Guide to the methods of technology appraisal, 2013 (https://www.nice.org.uk/process/pmg9/resources/guide-to-the-methods-of-technologyappraisal-2013-pdf-2007975843781)

34. National Standards for Public Involvement in Research. Multi-stakeholder group: INVOLVE, National Institute for Health Research, 2017; Access mode: https://sites.google.com/nihr.ac.uk/pi-standards/home.

35. Opportunities for efficiency in R\&D; KPMG public document; 2017 (https://home.kpmg/uk/en/home/insights/2017/ 09/opportunities-for-efficiency-in-r-and-d.html accessed 12 Feb 2019). 
36. Opposites attract: pairing R\&D and Commercial teams. Executive Insight public doc; May 05, 2015: https://www.executiveinsight.ch/en/insights/opposites-attract-pairing-rd-and-commercial-teams.

37. Patient Centricity Frameworks. A practitioner's guide; Eyeforpharma, December 2017.

38. Patient Input in Relative Effectiveness Assessments, The European Network for Health Technology Assessment, June $14^{\text {th }} 2019$, (https://www.eunethta.eu/wp-content/uploads/2019/06/Final_290519_Patient-Input-in-REAs.pdf).

39. Patient-centric pharma: Advancing the new business model; A First Word Expert Views Dossier Report; October 2016.

40. PCORI Funded Projects: Sample Engagement Plans From Methods Portfolio, August 6, 2014. Access mode: http://www.pcori.org/sites/default/files/PCORI-Sample-Methods-Engagement-Plans.pdf.

41. PCORI Patient Engagement Rubric Engagement Rubric for Applicants, Feb 4, 2014 (updated June 6, 2016). Access mode: http://www.pcori.org/sites/default/files/Engagement-Rubric.pdf.

42. People and Communities Board. Six principles for engaging people and communities: Definitions, evaluation and measurement. Published by the People and Communities Board, with support from National Voices, UK; June 2016; Access mode: https://www.nationalvoices.org.uk/sites/default/files/public/publications/six_principles_-_definitions_evaluation_and_ measurement_-_web_high_res_0_1.pdf.

43. Perfetto et al. Framework: When is evidence sufficient for decision-making? A framework for understanding the pace of evidence adoption, in Journal of Comparative Effectiveness Research, July 2013, Vol. 2, No. 4, Pages 383-391. Access mode: http://www.futuremedicine.com/doi/pdfplus/10.2217/cer.13.39.

44. Proctor E, Silmere H, Raghavan R, et al. Outcomes for Implementation Research: Conceptual Distinctions, Measurement Challenges, and Research Agenda. Adm Policy Ment Health (2011) 38:65-76.

45. Pushparajah DS. Making Patient Engagement a Reality. The Patient - Patient-Centered Outcomes Research, 2017, 11(1), 1-8. doi:10.1007/s40271-017-0264-6.

46. Rogers, E. Diffusion of Innovations. (4th ed.); 1995. New York, NY: The Free Press.

47. Scott AM, Wale JL; HTAi Patient and Citizen Involvement in HTA Interest Group, Patient Involvement and Education Working Group. Patient advocate perspectives on involvement in HTA: an international snapshot. Res Involv Engagem. 2017;3:2. Published 2017 Jan 10. doi:10.1186/s40900-016-0052-9.

48. Scottish Medicines Consortium. Making a submission, 2017 (https://www.scottishmedicines.org.uk/media/2792/ patient-group-partner-guide.pdf).

49. Skovlund SE, Gorbenko OV, Richards DP, et al. What are the priority patient engagement activities in medicines development? Results of a global multi-stakeholder consultation. PNS249 Research Poster J12, ISPOR, New Orleans, Louisiana, US; 19-22 May 2019.

50. Taylor J. Oral presentation at the Patient Summit Europe 2018, session "Discover the organisational blueprint for scaling patient centricity" / Being Patient-Centric: A National Voices Perspective; 16 October, London; https://s3.amazonaws.com/efpharma/patient2018/slides/D2-26+(b)+Jeremy.pdf.

51. The Canadian Agency for Drugs and Technologies in Health. Providing Input to CADTH, 2019 (https://www.cadth.ca/provide-input).

52. The French National Authority for Health. Develop quality in the health, social and medico-social field, 2019 (https://www.has-sante.fr/jcms/c_2891593/fr/conseil-pour-l-engagement-des-usagers; https://www.has-sante.fr/jcms/c_415958/ en/mission-and-budget).

53. The PFMD Book of Good Practices. May 2018; Patient Focused Medicines Development www.PatientFocusedMedicine.org.

54. Toledo-Chávarri A, Perestelo-Pérez L, Álvarez-Pérez Y, Abt-Sacks A, Santoro Domingo P, Villalón D, et al. Participación de los pacientes en la Evaluación de Tecnologías Sanitarias: manual metodológico. Ministerio de Sanidad, Servicios Sociales e Igualdad. Servicio de Evaluación del Servicio Canario de la Salud, 2016.

55. University of Maryland M-CERSI Framework. Assessing meaningful patient engagement in drug development: a definition, framework, and rubric, March 2015. Access mode: http://www.pharmacy.umaryland.edu/media/SOP/ wwwpharmacyumarylandedu/centers/cersievents/pfdd/mcersi-pfdd-framework-rubric.pdf.

56. Williams M. An analysis of the impact and barriers to patient engagement from the perspective of patient associations and pharma companies; Poster presentation at the $9^{\text {th }}$ European Conference on Rare Diseases \& Orphan Products, $10^{\text {th }}-12^{\text {th }}$ May 2018, Vienna; Access mode: (http://download2.eurordis.org.s3.amazonaws.com/ecrd/ECRD_2018/Poster\%20 PDFs/theme\%208/P211.pdf).

57. Williams M. Working together towards a collaborative future: Patient engagement from pharma and patient associations perspectives; Oral presentation at the $27^{\text {th }}$ EURORDIS Round Table of Companies Workshop; 16 ${ }^{\text {th }}$ October 2018, Barcelona; Access mode: (https://www.eurordis.org/publication/27th-eurordis-round-table-companies-workshop).

58. Woolley K, et al. Elevate Magazine. MAPS 2018; Access mode: https://maps.instantmagazine.com/publications/ elevate-magazine/patient-involvement-in-publications . Accessed April 16, 2019.

59. Working with patients and patient organisations. A sourcebook for industry. Version 1 - June 2019. The Association of the British Pharmaceutical Industry, 2019. 
60. Yeoman G, Furlong P, Seres M, et al. Defining patient centricity with patients for patients and caregivers: a collaborative endeavour. BMJ Innovation (published online ahead of print March 24, 2017). http://dx.doi.org/10.1136/bmjinnov2016-000157.

61. Zangi HA, Ndosi M, Adams J, et al. EULAR recommendations for patient education for people with inflammatory arthritis. Ann Rheum Diseases 2015; 74:954-962.

Дата надходження рукопису до редакції: 08.08.2019 р.

The biopharmaceutical industry is still on the path to patient centricity, in which a key challenge is to establish new ways of working, key performance indicators and operational models. There is currently no unified approach to measuring the success of patient engagement and patient centricity across the industry.

Methods. A literature search and broader resource analysis was conducted to identify and select frameworks, conceptual models and other relevant initiatives across the biopharmaceutical industry and healthcare systems focused on performance management and success evaluation within patient centeredness, over the period of 2010-2019. The selected resources were initially assessed against their key characteristics, targeted stakeholders, medicine lifecycle stage and proposed key elements (standards, attributes, criteria, KPIs and other indicators). Following, a deep content-analysis of the key elements was conducted, in which the key elements were categorised based on being attributable or infrastructural/procedural.

Results. 192 results were found through the literature search and 13 from the broader resource analysis. 12 frameworks and conceptual models were identified and selected as relevant; 4 targeted to the industry and 8 targeted to several stakeholders, including industry. Analysis of the selected frameworks/conceptual models demonstrated their significant diversity, heterogeneity and inconsistency in terms of their presented format, purpose, key objectives, targeted medicine lifecycle stage or industry/healthcare operations and proposed key elements. Categorisation of the 30 key elements led to 11 as attributable elements and 19 as infrastructural/procedural elements. Certain key elements featured higher cross-referencing within the analysed frameworks/conceptual models: diversity and representativeness, reciprocity, transparency, capacity and capabilities for engagement, meaningfulness, roles and responsibilities (attributable elements), valued products and quality product information (infrastructural/procedural element).

Conclusions. There is a first attempt to categorise and analyse the frameworks and conceptual models of patient centricity developed over the last decade. These findings should be the subject for further research and publications, in particular with the focus on piloting, validation and broader adoption of certain patient-centric standards, impact indicators and/or KPIs across the several organisations of biopharmaceutical industry.

Біофармацевтична індустрія наразі знаходиться на шляху до пацієнт-орієнтованості, де в якості основних перешкод залишаються запровадження шляхів роботи, ключових індикаторів виконання завдань і операційних моделей. На сьогоднішній день не існує будь-яких уніфікованих галузевих підходів до визначення успіху взаємодіі представників галузі з пацієнтами і пацієнт-орієнтованості в цілому.

Методи. Був проведений літературний пошук і всебічний аналіз ресурсноі бази за період 2010-2019 років для визначення і селекціі рамкових платформ, концептуальних моделей та інших дотичних ініціатив у біофармацевтичній галузі та системах охорони здоров'я, що були спрямовані на визначення ефективності та оцінку критеріів успіху пацієнт-орієнтованості. Вибрані ресурси були в першу чергу характеризовані на предмет цільових груп, цільових стадій розвитку/еволюційний фаз продукту та запропонованих основних елементів (стандартів, атрибутів, критеріів, ключових індикаторів виконання завдань та інших показників). Після цього був проведений глибинний контент-аналіз цих елементів, на основі якого вони були категоризовані як атрибутивні або інфраструктурні/процедурні.

Результати. 192 результати було знайдено в результаті літературного пошуку і 13 результатів було знайдено в результаті ширшого аналізу наявних ресурсів. 12 рамкових платформ та концептуальних моделей було ідентифіковано та обрано як дотичні до тематики дослідження; 4 - 3 виключним фокусом на біофармацевтичну галузь і 8 - 3 фокусом на різних операторів охорони здоров’я, включаючи біофармацевтичну галузь. Провединий аналіз рамкових платформ і концептуальних моделей показав їх істотну відмінність між собою, неоднорідність і невідповідність 3 огдяду на формат, цілі, основні завдання, цільові фази розвитку/еволюціі продукту або операційного менеджменту, а також запропоновані основні елементи. Категоризація 30 основних елементів дозволила виділити 11 як атрибутивні та 19 як інфраструктурні/ процедурні елементи. Певні елементи характеризувались більшою повторюваністю у платформах і моделях, як от: відмінність і репрезентативність, обопільність, прозорість, можливості та ресурсність для роботи 3 пацієнтами, значимість, ролі і відповідальність (атрибутивні елементи), цінність продукту і якісна інформація щодо продукту (інфраструктурний/процедурний елемент).

Висновки. Наразі це перша спроба категоризаціі та аналізу рамкових платформ та концептуальних моделей пацієнт-орієнтованості, що були розроблені протягом останніх 10 років. Ці результати мають бути суб’єктом подальших досліджень і публікацій, зокрема у частині пілотування, валідаціі та ширшого впровадження певних стандартів, індикаторів впливу та/або ключових індикаторів виконання завдань щодо пацієнт-орієнтованості 3 боку різних організацій біофармацевтичної галузі. 
В данное время биофармацевтическая индустрия находится на пути к пациент-ориентированности, где в качестве основных преград остаются внедрение путей работы, ключевых индикаторов выполнения заданий и операционных моделей. На сегодня не существует каких-либо унифицированных отраслевых подходов к определению успеха взаимодействия представителей отрасли с пациентами и пациент-ориентированности в целом.

Методы. Был проведен литературный поиск и всесторонний анализ ресурсной базы за период 2010-2019 годов для определения и селекции рамочных платформ, концептуальных моделей и других релевантных инициатив в биофармацевтической отрасли и системах здравоохранения, которые были направлены на определение эффективности и оценку критериев успеха пациент-ориентированности. Выбранные ресурсы были в первую очередь охарактеризованы на предмет целевых групп, целевых стадий развития/эволюционных фаз продукта и предложенных основных элементов (стандартов, аттрибутов, критериев, ключевых индикаторов выполнения заданий и прочих показателей). После этого был проведен глубинный контент-анализ данных элементов, на основании чего они были категоризированы на аттрибутивные и инфраструктурные/процедурные.

Результаты. 192 результата было найдено в ходе литературного поиска и 13 результатов було найдено в ходе более расширенного анализа существующих ресурсов. 12 рамочных платформ и концептуальных моделей были идентифицированы и выбраны как относящиеся к тематике исследования; 4 - с исключительным фокусом на биофармацевтическую отрасль и 8 - с фокусом на различных операторов здравоохранения, включая биофармацевтическую отрасль. Проведенный анализ рамочных платформ и концептуальных моделей показал их существенное различие между собой, неоднородность и несоответствие с точки зрения формата, цели, основных заданий, целевых фаз развития/эволюции продукта и операционного менеджмента, а также предложенных основных элементов. Категоризация 30 основных елементов позволила выделить 11 в качестве аттрибутивных и 19 в качестве инфраструктурных/процедурных. Определенные элементы характеризовались большей степенью повторяемости в платформах и моделях, а именно: разнородность и репрезентативность, обоюдность, прозрачность, возможности и ресурсность для работы с пациентами, значимость, роли и ответственность (аттрибутивные элементы), ценность продукта и качественная информация в отношении продукта (инфраструктурный/процедурный элемент).

Выводы. На данный момент это первая попытка категоризации и анализа рамочных платформ и концептуальных моделей пациент-ориентированности, которые были разработаны на протяжении последних 10 лет. Эти результаты должны стать субъектом дальнейших исследований и публикаций, особенно в аспекте пилотирования, валидации и более широкого внедрения определенных стандартов, индикаторов влияния и/или основных индикаторов выполнения заданий в отношении пациент-ориентированности со стороны разных организаций биофармацевтической отрасли.

Конфлікт інтересів: відсутній.

Conflicts of interest: authors have no conflicts of interest to declare.

\section{Відомості про авторів}

Gorbenko Oleksandr - MD, PhD, Global Director, Patient Affairs, ViiV Healthcare, TW8 9GS, 980 Great West Road, Brentford, Middlesex, United Kingdom.

algostand@gmail.com.

Williams Merlin - MSc, Senior Consultant, Executive Insight Healthcare Consultants AG, Baar, Switzerland. m.williams@executiveinsight.ch. 